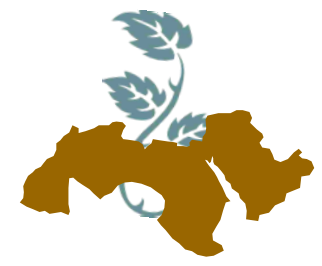

Arab Univ.

J. Agric. Sci., Ain Shams Univ., Cairo Special Issue, 26(2C), 1881 - 1894, 2018

\title{
ISOLATION, IDENTIFICATION AND BIOCONTROL OF SALMONELLA TYPHIMURIUM IN KARIESH CHEESE BY BACTEIOPHAGE
}

\author{
Mona S. Ali ${ }^{1}$, Ragia O. Mohamed ${ }^{2}$, Hassan ${ }^{1}$ M.A. and Fayed ${ }^{2}$ A.E.
}

1- Food Technol., Res. Inst., Agriculture Research Center, Giza, Egypt.

2- Food Sci. Dept., Fac. of Agric., Ain Shams Univ., P.O. Box 68 Hadayek Shoubra 11241, Cairo, Egypt

E-mail: profateffayed@yahoo.com

Keywords: Salmonella typhimurium identification by polymerase chain reaction (PCR), Morphology particles of Salmonella bacteriophage examination by transmission electron microscope, Cheese properties

\section{ABSTRACT}

The study aims to assess the possibility of biological control on one of the most serious pathogenic microbes that found to infect Kariesh cheese, namely Salmonella typhimurium.

To achieve this object, firstly a total of 20 Kariesh cheese samples were collected randomly from various markets located at Cairo and exposed to microbiological isolation and identification of $S$. typhimurium. The obtained results revealed that, $S$. typhimurium was detected in $30 \%$ of surveyed market Kariesh cheese according to the strain identified by polymerase chain reaction (PCR) technique. Secondary, five sewage water samples were obtained from Fac. of Agric., Ain Shams Univ., and Shoubra EL-Kheima station of drinking and sewage water for specific bacteriophage isolation and morphology particles of Salmonella bacteriophage was examined by transmission electron microscope. Third, pasteurized skimmed buffalo's milk was converted into experimental Kariesh cheese at $40^{\circ} \mathrm{C}$ by milk inoculation with $2 \%$ of freshly activated yoghurt bacterial starter culture and then milk was divided into 5 equal portions. The $1^{\text {st }}$ portion considered as control. The $2^{\text {nd }}, 3^{\text {rd }}$, $4^{\text {th }}$ and $5^{\text {th }}$ portions were contaminated with equal level $(1 \%)$ of $S$. typhimurium suspension containing $10^{5}$ colony forming units $(\mathrm{CFU}) / \mathrm{mL}$, previously isolated from foregoing surveyed Kariesh cheese samples, followed by adding phage suspension, from which isolated from sewage water, containing $10^{8}$ plaque forming units (PFU) $/ \mathrm{mL}$ at the levels of nil, 1, 2 and $3 \%$ respectively. All portions were separately incubated at the same temperature up to curdling. The curds were cut and individually filled into stainless steel moulds lined with cheese cloth and consolidated by a slight pressure for 24 h. The blocks of curd were then cut, dry salted using $2 \% \mathrm{NaCl}(\mathrm{w} / \mathrm{w})$ and packaged into plastic containers.

Experimentally, there were proportional reductions in lactic acid bacteria (LAB) population as the level of phage spiked into cheese milk increased, as which the reduction rate of $L A B$ count during cold storage period (CSP) prolonging was however declined.

In terms of health safety, although the number of pathogen microbe added was gradually reduced due to the acid developed by prolonging the Cold Storage Period in the absence of phage, but it stilled present until the end of experimental period. While, the pathogen was completely eliminated within 7 days of cheese age when the phage suspension $\left(10^{8} \mathrm{PFU} / \mathrm{mL}\right)$ has been spiked at the level of $1 \%$ at least.

The contamination of experimental Kariesh cheese with $S$. typhimurium led to weaken the ability of cheese curd to drain whey as explained from the dry matter (DM) content which decreased due to the presence of pathogen and increased by the pathogen elimination with bacteriophage, which resulted also to increase the protein /DM content. The ash content reduced by both reasons, namely the contamination with $S$. typhimurium and/or the spiking level of phage suspension. The presence of $S$. typhimurium slowed the LAB population and acid production by them. 
Finally, as a conclusion, the spiking of Kariesh cheese milk with $1 \%$ Salmonella typhimurium phage suspension $\left(10^{8} \mathrm{PFU} / \mathrm{mL}\right)$ is quite enough to eliminate this microorganism when it present at the level of $1 \%$ suspension containing $10^{5} \mathrm{CFU} / \mathrm{mL}$.

\section{INTRODUCTION}

White soft cheese is one of the common delicious cheeses consumed in Egypt. There are many varieties of white soft cheese depend on the technique of manufacture, salt percentage and many other factors. White soft cheese is conventionally manufactured from cow or buffalo milk or a mixture of them according to the Egyptian cheesemaking technology (Abd El-Salam et al 1976 and Abou-Donia, 1991). Production may be artisanal or industrial, depending on whether the cheeses are manufactured with raw thermized (heated below pasteurization level) or pasteurized milk (AbdEI Salam and Benkerroum, 2006 and Ibrahim and Sobeih, 2010).

Skimmed milk (Kariesh) cheese is one of the indigenous white soft cheese types in Egypt. Kariesh as well as Domiati chesses are the most popular varieties of soft cheese in Egypt, but the former is the oldest type manufactured since 3000 B.C. Kariesh cheese occupies a significant space in the consume cheese market. It composes of about $50 \%$ of white soft cheeses produced in Egypt (Abou-Donia, 1991; Hegazy et al 2012 and Fayed et al 2013 and 2014). Kariesh cheese is usually produced from skimmed milk using acidification coagulants containing about $70 \%$ moisture and not more than $10 \%$ fat (El Gendy, 1983; Fayed, 1986 and Fayed et al 2013 and 2014).

In the past traditional Kariesh cheese had been made on the farms from "Rayeb" milk. The latter is a naturally developed acidity coagulant during gravity creaming in earthenware containers. After skimming the sour cream, the "Rayeb" milk is drained in folded mats. Draining of the whey takes two or three days, or until the desired texture of cheese is obtained. Finally, cheese is cut into suitable pieces, then dry salted to taste. The salted cheese is left for a few more hours in the mat until no more whey drains out and is then ready to be consumed as fresh cheese. Resultant cheese is either consumed fresh or after pickling in available farm-house milk by-products, e.g. butter milk, "Murta", whey ... etc. (Fayed, 1986).

When, centrifugal separators are used, this cheese is conventionally produced by acid coagulation of mechanically skimmed milk by culturing with lactic acid bacteria. Skimmed milk results infe- rior Kariesh cheese type due to lower fat content in separator's skimmed milk. The quality and composition of Kariesh cheese may vary considerably due to such factors affecting the quality and composition of the clotted skimmed milk, the method of manufacture, the time required to complete the drainage of whey, the quality of salt added and the method of handling the finished cheese (Fahmi, 1950; El-Gendy, 1983; Abou-Donia, 1984, 1991, 1999 a, b and 2008).

In spite of cheese was previously classified under "safe foods" but across ages, many reports of infections and the intoxications related to the consumption of contaminated cheese which poses a threat to public health and also quality defects in cheese leads to big economic losses (Lindqvist et al 2002).

From a health standpoint, Kariesh cheese continues to suffer from many microbial infections, including pathogens across ages. The pathogenic Escherichia coli $\mathrm{O} 157 \mathrm{H} 7$ has been isolated from $19 \%$ out of 15 Kariesh cheese samples collected from Cairo \& Giza governorate markets (El-Sayed et al (2011). The logarithmic (log) mean values of Staphylococcus aureus count were $5.0 \pm 0.2 \mathrm{CFU} / \mathrm{g}$. Enterobacteriacae were found in the examined samples with the log mean values of $4.5 \pm 0.1$ CFU/g. Moreover, E. coli was detected in the examined samples with log mean values of $4.3 \pm 0.6$ $\mathrm{CFU} / \mathrm{g}$. The prevalence rate of Salmonella spp. was $10 \%$ out of 60 samples (Ibrahim et al 2015). In another study, a total of 200 cheese samples (100 Kariesh cheese and 100 Domiati cheese) was collected randomly from different supermarkets and retailer shops in Cairo and Giza governorates. Samples were analyzed for total colony count (TCC), total coliforms, E. coli, Staph. aureus, Bacillus cereus and yeast and mold counts, as well as for the pathogens E. coli O157:H7 and Salmonella spp. Both Kariesh and Domiati cheese samples were found to be highly contaminated, having bacterial load exceeding the acceptable limit. The microbiological quality of both cheeses was judged as poor. Pathogenic bacteria (E. coli, B. cereus and Staph. aureus) were detected in some of the cheese samples (Hassan and Gomaa, 2016).

That in view is leading to report that hence Kariesh cheeses were contaminated with different types of microorganisms giving an indication of poor sanitary conditions may present a public health hazard to the consumers and emphasizes the need for improved hygienic standard, so strict hygienic measures, efficient heat treatment, and application of HACCP system should be performed. 
Consumers dislike the use of chemical preservatives in their food, and with some there is an associated public health risk. This increases the pressure for these chemicals to be removed from food and for the adoption of more "natural" means of preservation. While there are a variety of approaches to using natural preservatives, the most often adopted approach to date has been to use bio-control (McLntryre et al 2007). The use of biological factors against various pathogenic and saprophyte microorganisms, especially pathogenic bacteria, is defined as a bio-control. The use of bacteriophage as a bio-control factor proposed shortly after the discovery of bacteriophage two times independently by d'Herelle (1917). Unfortunately, bacteriophage studies have been eliminated with the discovery antibiotics. Recently, the studies of use of bacteriophages as a bio-control factor (phage therapy) revived because of increasing antibiotic resistances. Usually, these studies are concentrated about food safety, especially food pathogens such as E. coli O157:H7, Campylobacter, Salmonella and Listeria causing epidemics of disease (Hages and Loessner, 2007).

Bacteriophages are natural enemies of bacteria and are suitable candidates for the environmentally friendly biocontrol of these pathogens. In recent years, researchers tended to bring new alternative to biological protective systems used in conservation of food and production of safe food. Use of bacteriophage against to pathogen bacteria in food was the most hopeful system in these methods about bio-control. Controls of bacteriophage for each pathogen species and subspecies and determination of phage-host originality are important because efficient bio-control was achieved. Researches concentrated on some food-borne pathogen bacteria such as E. coli O157:H7, Campylobacter, Salmonella and Listeria. In a consequence of these studies made as in vitro and in vivo, first commercial production of phage which will be used in foods was made in Netherlands. Also, it has been informed that use of phage is cost-efficient alternative as compared with other preservatives. This review, discussed application of bacteriophages as bio-control agents in food and advantages and disadvantages about uses of bacteriophages by taking into account antimicrobial characteristics of them (Kalkan et al 2011).

For that in view, the study aims to assess the possibility of biological control on one of the most serious pathogenic microbes that found to infect Kariesh cheese, namely Salmonella typhimurium.

\section{MATERIALS AND METHODS}

\section{Materials}

A total of 20 Kariesh cheese samples were randomly collected during the period of May - June 2014 from various markets located at Cairo. Samples were transported under aseptic condition to the laboratory.

Pasteurized buffalo's skimmed milk $(0.5 \%$ fat and $8.5 \%$ solids not fat) was obtained from the herd of the dairy cattle at faculty of Agriculture, Cairo Univ., Egypt.

Five sewage water samples were obtained from Fac. of Agric., Ain Shams Univ., and Shoubra EL-Kheima station of drinking and sewage water. Before sampling the external surfaces were scrubbed with alcohol, flaming and taps were flushed. The obtained samples were taken in sterile amber glass bottle of $250 \mathrm{ml}$ capacity and directly transferred to the Virology Lab., Agric. Microbiol. Dept., Fac. of Agric., Ain Shams Univ. in refrigerated container and then maintained at $4-8^{\circ}$ C. The microbiological analysis was carried out within $12 \mathrm{~h}$ of sampling, including bacteriophage isolation.

Concentrated lyophilized yoghurt bacterial culture (YC-183) consisting of Streptococcus thermophillus and Lactobacillus delbruckii ssp. bulgaricus (1:1) was obtained from Chr. Hansen's Lab A/S Copenhagen, Denmark.

Sodium chloride $(\mathrm{NaCl})$ was obtained from $\mathrm{El}-$ Nasr for salt production Co.

\section{Experimental procedure}

\section{Preparation of bacterial starter cultures}

Preparation of YC-183 starter culture was carried out by dissolving $15 \mathrm{~g}$ of the lyophilized culture in 1 liter UHT skimmed milk and incubation at $40 \pm$ $1^{\circ} \mathrm{C}$ up to curdling, whereat it usually coagulated throughout $3 \mathrm{~h}$.

\section{Isolation and identification of Salmonella typhimurium}

Salmonella sp. was isolated and enumerated as CFU/g according standardized procedures for microbiological examination of food products as described by (AOAC, 2007). The $1^{\text {st }}$ step of detection Salmonella sp. was carried out by inoculation with $25 \mathrm{~g}$ from cheese sample to $225 \mathrm{ml}$ of buffered peptone water and incubated at $37^{\circ} \mathrm{C}$ for 18 
h. The $2^{\text {nd }}$ step performed in $10 \mathrm{ml}$ tetra thionate broth medium and $1 \mathrm{ml}$ from $1^{\text {st }}$ step was added and then incubated at $37^{\circ} \mathrm{C}$ for $24 \pm 2 \mathrm{~h}$. In the $3^{\text {rd }}$ step, $1 \mathrm{ml}$ from $2^{\text {nd }}$ step was poured in Petri dish and directly followed by xylose lysine deoxycholate (XLD) or Bismuth Sulphate agar medium (25 mL medium per plate) and incubated for $24 \pm 3 \mathrm{~h}$ at $37^{\circ} \mathrm{C}$.

Salmonella typhimurium was identified by Polymerase chain reaction (PCR) (Bio rad T100 thermal circular) according to Official method described by Lim et al (2003).

\section{3 .Preparation of Salmonella typhimurium sus- pension}

Salmonella typhimurium suspension was prepared according to Fiorentin et al (2005).

\section{Phage screening in sewage water in relation to isolated Salmonella typhimurium}

Qualitatively, the crude lysate of Salmonella phages was assayed qualitatively using the spot test according to Borrego et al (1987). Three $\mathrm{mL}$ of nutrient broth medium containing $0.7 \%$ agar were inoculated with $1 \mathrm{ml}$ of Salmonella sp. culture containing $10^{9} \mathrm{CFU} / \mathrm{mL}$ and then poured onto nutrient agar petri dishes after gently mixing. After solidification, $100 \mu \mathrm{L}$ of crude Salmonella phage lysate were spotted on surface of media and incubated at $37^{\circ} \mathrm{C}$ overnight. The clear lysis zone in the sites of spots was recorded as indication the presence of phage.

Quantitatively, the isolation of viruses was carried out according to Othman (1997) by the double-layer technique using NA-Ca ${ }^{2+}$ agar inoculated with a selected propagative culture; the plates were incubated at $37^{\circ} \mathrm{C}$ for $16 \mathrm{~h}$. A single plaque was picked up and mixed with a fresh culture (O.D. $600 \mathrm{~nm}=0.15$ ) of the indicator strain, after lysis it was centrifuged at $3500 \mathrm{rpm}$ for $15 \mathrm{~min}$ and then filtered through a $0.45 \mu \mathrm{m}$ membrane, this procedure was repeated twice the titer of the phage suspension was defined as PFU $/ \mathrm{mL}$.

The crude lysate of Salmonella phages were assayed quantitatively according to Othman (1997) by the soft-agar overlay (double ager layer) method using nutrient agar medium inoculated with Salmonella sp. and incubated at $37^{\circ} \mathrm{C}$ for $16 \mathrm{~h}$.

Morphology particles of Salmonella bacteriophage was examined using $2 \%$ uranyl acetate as negative staining Luftig (1967) and Othman (1997) by transmission electron microscope.

\section{Preparation of Salmonella bacteriophage stock (single plaque)}

Biologically stock phage lysate was obtained by the method reported by Othman et al (2008) using the single plaque isolation method. A large amount of the phage stock was obtained by propagation the phage by the liquid culture propagation method used by Othman et al (2008). To amplify the phages, $10 \mathrm{ml}$ of an overnight culture of bacterial cells $\left(10^{9} \mathrm{CFU} / \mathrm{mL}\right)$ and $1 \mathrm{~mL}$ of the phage $\left(10^{11}\right.$ $\mathrm{PFU} / \mathrm{mL}$ ) were added to $500 \mathrm{~mL}$ of broth media and incubated with shaking at $37 \stackrel{\circ}{\circ}$ for $5 \mathrm{~h}$. After incubation, the bacterium-phage suspension was treated with $10 \mathrm{~mL}$ of chloroform to release any progeny phage which might still have been in the host cells, and the suspension was incubated for an additional $10 \mathrm{~min}$ with hard shaking. To remove bacterial debris, the suspension was centrifuged at $6000 \mathrm{rpm}$ for $15 \mathrm{~min}$, and the supernatant was withdrawn and filtered through $0.22-\mu \mathrm{m}$-pore-size filters. The phage lysates were stored at $4^{\circ} \mathrm{C}$ as described by Goodridge et al (2001).

\section{Preparation of crude Salmonella phage suspension}

$250 \mathrm{~mL}$ Erlenmeyer flask containing $100 \mathrm{~mL}$ of nutrient broth medium was inoculated with $10 \mathrm{~mL}$ of the tested sewage water and $10 \mathrm{~mL}$ of Salmonella strain was mixed. The flasks were incubated at $37^{\circ} \mathrm{C}$ for $48 \mathrm{~h}$ with (LAB Line instruments Inc. model No.3526-4GMLB. After incubation the cultures were centrifuged at $6000 \mathrm{rpm}$ for $15 \mathrm{~min}$ and the supernatant was collected into a clean flask. Chloroform was added with rate of 1:10 followed with vigorously shaking for $5 \mathrm{~min}$. The crude lysate of the phages were obtained and assayed qualitatively and quantitatively according to Borrego et al (1987).

\section{Manufacturing procedures of conventional Kariesh cheese}

The procedure protocol of conventional Kariesh cheesemaking was applied as described by Fahmi (1950), Fayed (1986) and Fayed et al (2013). Pasteurized skimmed buffalo's milk was heated at $40^{\circ} \mathrm{C}$, inoculated with $2 \%$ of freshly activated YC starter culture and then divided into 5 equal portions. The $1^{\text {st }}$ portion was the control. The $2^{\text {nd }}, 3^{\text {rd }}$, $4^{\text {th }}$ and $5^{\text {th }}$ portions were contaminated with equal levels (1\%) Salmonella typhimurium suspension containing $10^{5}$ colony forming units (CFU)/mL fol- 
lowed by adding phage suspension $10^{8}$ plaque forming units (PFU)/mL at the levels of nil, 1, 2 and $3 \%$ respectively. All portions were separately incubated at the same temperature up to curdling. The curds were cut and individually filled into stainless steel moulds lined with cheese cloth and consolidated by a slight pressure for $24 \mathrm{~h}$. The blocks of curd were then cut, dry salted using $2 \% \mathrm{NaCl}(\mathrm{w} / \mathrm{w})$ and packaged into plastic containers (Fig. 1). Three replicates were carried out for each treatment.

\section{Analytical methods}

\section{Chemical analyses}

Dry matter (DM), fat, protein, ash and titratable acidity (TA) were determined according to AOAC (2007). The $\mathrm{NaCl}$ content was determined according to method of Van der Burg, which described by Kotterer and Munch (1978). The $\mathrm{pH}$ value was measured electrometrically using Lab. pH meter with a glass electrode, Hanna model 8417 digital $\mathrm{pH}$ meter.

\section{Enumeration of lactic acid bacteria}

Lactic acid bacteria count was determined using MRS agar according to De Man et al (1960). The plates were incubated at $35^{\circ} \mathrm{C}$ for $48 \mathrm{~h}$.

\section{Statistical analysis}

The obtained data were exposed to proper statistical analysis according to statistical analyses system user's guide (SPSS, 1998).

\section{RESULTS AND DISCUSSION}

\section{Safety situation of market conventional $\mathrm{Ka}-3$ riesh cheese towards Salmonella typhimurium}

Data illustrated in Table (1) indicated that Salmonella typhimurium was detected in $30 \%$ of surveyed market Kariesh cheese according to the strain identified by PCR technique and morphological shape pictured in Fig. (2 A\&B).

Moreover, as could be observed in the data given in the Table (1) that, $S$. typhimurium had appeared negative behavior towards the Gram test While it possessed catalase production. These results are in complete coincidence with those reported by Holt et al (1994).
Table 1. The occurrence percentage and biochemical characteristics of Salmonella typhimurium detected in surveyed Kariesh cheese during the period expended from May to July 2014.

\begin{tabular}{|l|c|}
\hline \multicolumn{1}{|c|}{ Criteria } & Result \\
\hline Percentage of infected samples & $30 \%$ \\
Biochemical characteristic & \\
Gram stain & - \\
Catalase & + \\
Growth temperature degree & \\
$30^{\circ} \mathrm{C}$ & ++++ \\
$37^{\circ} \mathrm{C}$ & +++ \\
$44^{\circ} \mathrm{C}$ & + \\
$51^{\circ} \mathrm{C}$ & - \\
$58^{\circ} \mathrm{C}$ & - \\
$65^{\circ} \mathrm{C}$ & - \\
Sugar fermentation & \\
Glucose & - \\
Manitol & - \\
Arabinose & - \\
Gelatine liquefaction & - \\
\hline
\end{tabular}

Concerning the growth ability at different temperatures, $S$. typhimurium could not grow at a temperature higher than $44^{\circ} \mathrm{C}$ (Table, 1 ). The forgoing results agree with those reported in Holt et al (1994).

Regarding the possibly of the detected pathogens for sugar fermentation, the obtained results declared that, Salmonella sp. could not ferment sugar, namely glucose, mannitol and arabinose. Also it did not able to liquate gelatin as present in Table (1). These results are in accordance with Holt et al (1994).

\section{2. Characteristics of specialized bacteriophage of Salmonella typhimurium}

Electron microscopy of Salmonella bacteriophage particles revealed that, the virus is long, curled non contractile tail. The phage particle has an isometric head with diameter of about $91.11 \mathrm{~nm}$ and the tail has $23.07 \mathrm{~nm}$ in length (Fig. 3). The phage assigned to family Myoviridae as indicated by the presence of along contractile tail.

Furthermore, spot test showing the bacterial lysis caused by virulent bacteriophage specific for S. typhimurium (Fig. 4). Likewise, plaque assay showing identical morphological plaques of $S$. typhimurium (Fig. 5). 


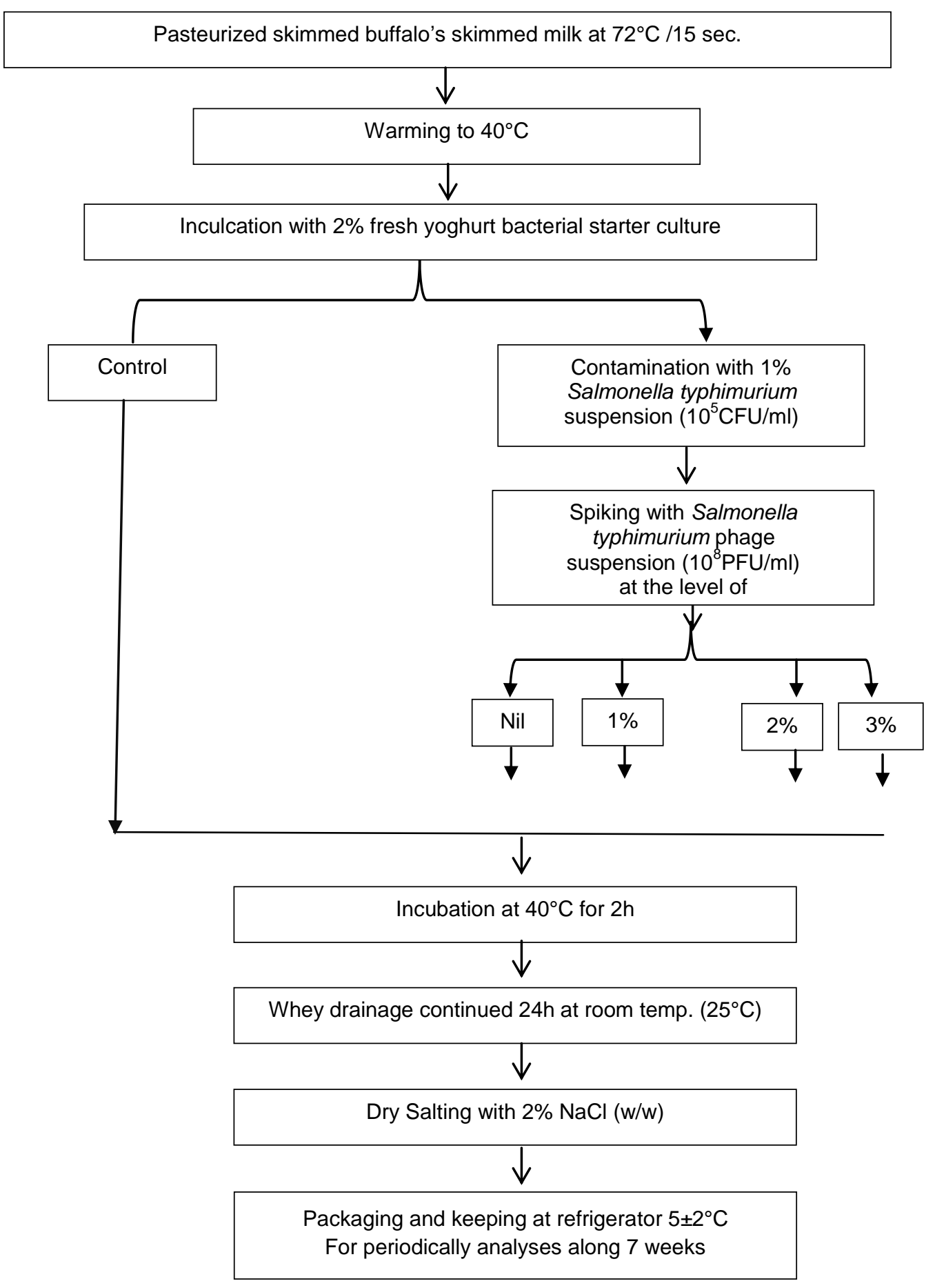

Fig. 1. Flow diagram of conventional Kariesh cheese making contaminated with Salmonella typhimurium and spiked with its phage 


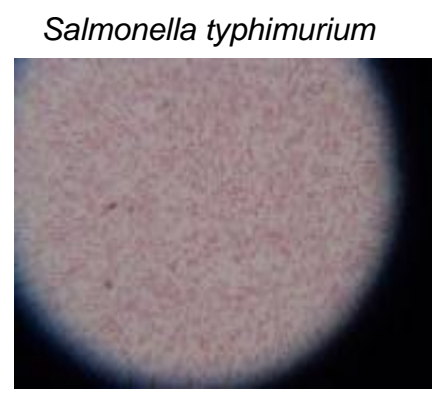

(A)

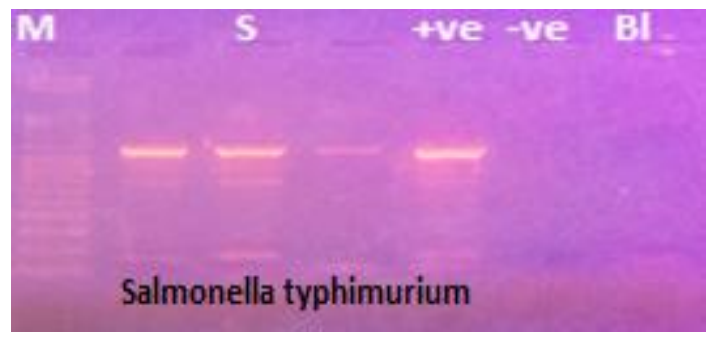

(B)

Fig. 2. Picture of Salmonella typhimurium colony by light microscope $(A)$ and by polymerase chain reaction (PCR) technique (B).

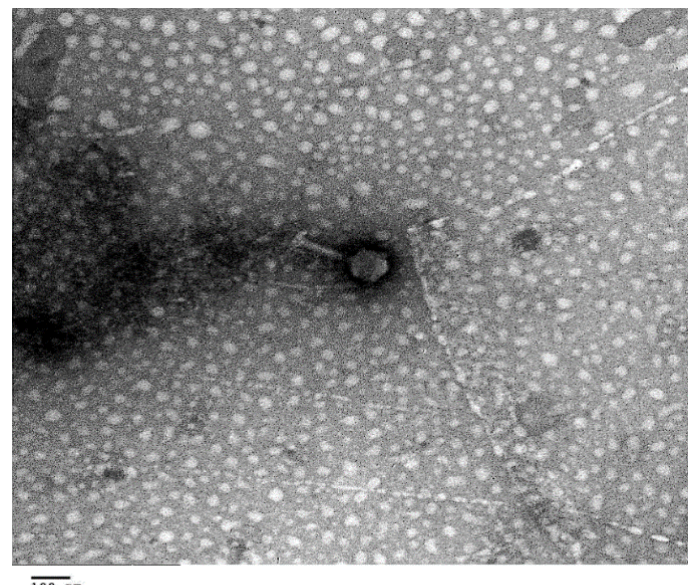

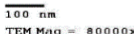

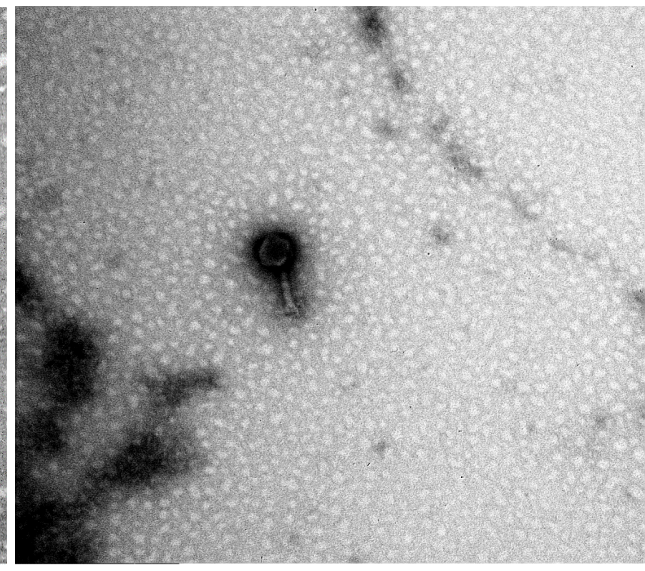

$\overline{1000 \text { in }}$

Fig. 3. Electron micrograph of purified Salmonella bacteriophage negatively stained with $2 \%$ uranyl acetate (Magnification X-80000)
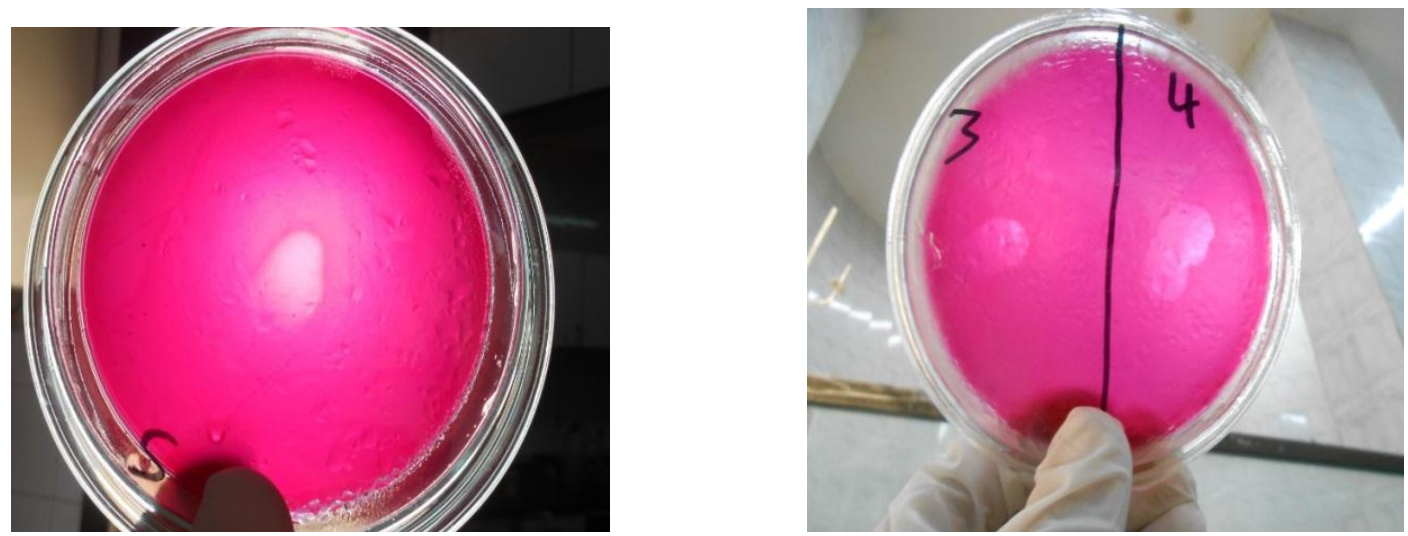

Fig. 4. Spot test showing the bacterial lysis caused by virulent bacteriophage specific for Salmonella typhimurium 


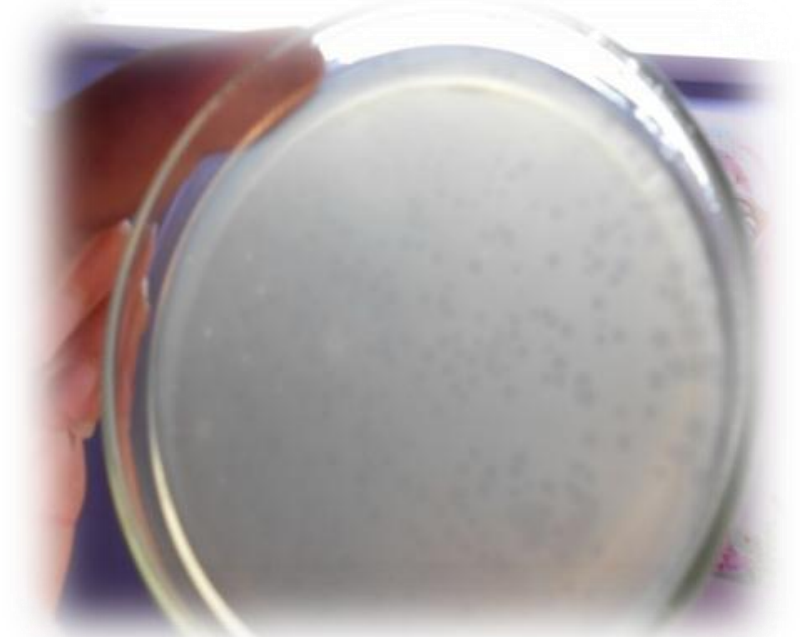

Fig. 5. Plaque assay showing identical morphological plaques of Salmonella typhimurium

Furthermore, the persistence study on the selected phage indicated its resistance ability towards a range of temperature degrees or $\mathrm{pH}$ values (Table, 2) making it could be suitable for the condition of Kariesh cheese manufacturing.

\section{Biocontrol of Salmonella typhimurium in Ka- riesh cheese by bacteriophage}

\subsection{Microbiological quality of Kariesh cheese}

Bacteriologically, there were proportional reductions in LAB population as the level of phage spiked into cheese milk increased, as which the reduction rate of $L A B$ count during CSP prolonging was however declined (Table, 3).

In terms of health safety, although the number of pathogen microbe added was gradually reduced due to the acid developed by prolonging the CSP in the absence of phage, but it stilled present until the end of experimental period. While, the pathogen was completely eliminated within 7 days of cheese age when the phage suspension $\left(10^{8}\right.$ PFU $/ \mathrm{mL}$ ) has been spiked at the level of $1 \%$ at least (Table, 3).

Table 2. Spot test of Salmonella bacteriophage particles along different temperature degrees for 7 days and $\mathrm{pH}$ values for one day

\begin{tabular}{|c|c|c|c|c|c|}
\hline \multirow{2}{*}{ Post survival (day) } & \multicolumn{5}{|c|}{ Temperature degree (C) } \\
\cline { 2 - 6 } & -20 & $\mathbf{4}$ & $\mathbf{2 4}$ & $\mathbf{3 7}$ & $\mathbf{4 2}$ \\
\hline 1 & + & + & + & + & + \\
3 & + & + & + & + & + \\
4 & + & + & + & + & + \\
5 & + & + & + & + & + \\
6 & + & + & + & + & + \\
7 & + & + & + & + & + \\
& + & + & + & + & + \\
\hline
\end{tabular}


Table 3. Microbiological quality (log CFU/g) of Kariesh cheese as affected either by the contamination with $1.0 \%$ Salmonella typhimurium suspension $\left(10^{5} \mathrm{CFU} / \mathrm{mL}\right)$ and/or spiking with different levels of its specific phage suspension $\left(10^{8} \mathrm{PFU} / \mathrm{mL}\right)$ during cold storage period (CSP) for 14 days

\begin{tabular}{|c|c|c|c|c|c|c|}
\hline \multirow{3}{*}{ Strain } & \multirow{3}{*}{ CSP(Day) } & \multirow{3}{*}{ Control } & \multicolumn{4}{|c|}{$\begin{array}{l}\text { Contamination with1\% Salmonella suspension } \\
\qquad\left(10^{5} \mathrm{CFU} / \mathrm{mL}\right)\end{array}$} \\
\hline & & & \multicolumn{4}{|c|}{$\begin{array}{l}\text { Spiking level with Salmonella typhimurium phage } \\
\text { suspension }\left(10^{8} \mathrm{PFU} / \mathrm{mL}\right)\end{array}$} \\
\hline & & & Nil & $1 \%$ & $2 \%$ & $3 \%$ \\
\hline \multirow[t]{3}{*}{ LAB } & Fresh & $5.78^{\mathrm{a}, \mathrm{a}}$ & $5.69^{\mathrm{a}, \mathrm{a}}$ & $4.62^{\mathrm{b}, \mathrm{a}}$ & $4.36^{\mathrm{b}, \mathrm{a}}$ & $3.89^{\mathrm{c}, \mathrm{a}}$ \\
\hline & 7 & $4.79^{a, b}$ & $2.79^{c, b}$ & $2.88^{\mathrm{c}, \mathrm{b}}$ & $3.66^{b, b}$ & $3.85^{\mathrm{b}, \mathrm{b}}$ \\
\hline & 14 & $1.77^{\mathrm{a}, \mathrm{c}}$ & $1.77^{\mathrm{a}, \mathrm{c}}$ & $1.90^{\mathrm{a}, \mathrm{c}}$ & $1.76^{\mathrm{a}, \mathrm{c}}$ & $1.92^{\mathrm{a}, \mathrm{c}}$ \\
\hline \multirow[t]{3}{*}{ Salmonella typhimurium } & Fresh & ND & 4.04 & 2.79 & 2.77 & 2.74 \\
\hline & 7 & ND & 1.55 & ND & ND & ND \\
\hline & 14 & ND & 1.30 & ND & ND & ND \\
\hline
\end{tabular}

LAB: Lactic acid bacteria $\quad$ ND: Not detected. $\quad$ CFU: Colony forming unit. $\quad$ PFU: Plaque forming unit.

The letters before comma possess the factor of contamination with1\% Salmonella suspension. While those after comma possess the factor of spiking level with Salmonella typhimurium phage suspension. The means with the same letter at any position did not significantly differ $(\mathrm{P}>0.05)$.

\subsection{Physiochemical properties of Kariesh cheese}

The results present in Table (4) indicated that, the dry matter (DM) contents of cheese varied significantly among either the contamination with $S$. typhimurium or the level of bacteriophage suspension spiked. Moreover, the letter of Dancan's test demonstrated that, the presence of $S$. typhimurium weakened the ability of cheese curd to drain whey while, the adequate control of pathogen with its bacteriophage has helped the curd to reject whey to be like the non-infected cheese curd (the control).

While, the prolonging of CSP to 14 days did not lead to any significant changes in the DM\% of all cheese samples studied (Table, 4).

It is worthy to mention that, DM\% of all samples are, indeed, in surrounding on the legal standard of EOSQ (2005), which provided that the DM content of Kariesh cheese should be not less than $25 \%$.
These results are in coincidence with those of Kariesh cheeses whether from street vendors or certain local brands regardless their ages reported by Bakry et al (2011) and Fayed et al (2013 and 2014).

Concerning the protein /DM content, date given in Table (4) show that, except of the control, there was a significant increment in the protein /DM content associated with the ascending spiking level with bacteriophage suspension. This phenomenon could be ascribed to the fact of the killing action possessed the phage added on the pathogen strain and hence the acidity became better developed leading to more whey drainage followed by increase in the protein portion in the DM. There is another reason, but to a lesser degree, structurally phages consist of a nucleic acid genome enclosed within a protein or lipoprotein coat as described by Guttman et al (2005). While the CSP along 14 days had no significant influence on this criterion. 
Table 4. Physiochemical properties of Kariesh cheese as affected either by the contamination with $1.0 \%$ Salmonella typhimurium suspension $\left(10^{5} \mathrm{CFU} / \mathrm{mL}\right)$ and/or spiking with different levels of its specific phage suspension $\left(10^{8} \mathrm{PFU} / \mathrm{mL}\right)$ during cold storage period(CSP) for 14 days

\begin{tabular}{|c|c|c|c|c|c|c|}
\hline \multirow{3}{*}{ Property } & \multirow{3}{*}{ CSP(Day) } & \multirow{3}{*}{ Control } & \multirow{2}{*}{\multicolumn{4}{|c|}{$\begin{array}{c}\text { Contamination with1\% Salmonella suspension } \\
\left(10^{5} \mathrm{CFU} / \mathrm{mL}\right)\end{array}$}} \\
\hline & & & & & & \\
\hline & & & Nil & $1 \%$ & $2 \%$ & $3 \%$ \\
\hline \multirow{3}{*}{$\begin{array}{l}\text { Dry matter } \\
\text { (DM)\% }\end{array}$} & fresh & $25.63^{a, a}$ & $25.09^{b, a}$ & $25.09^{b, a}$ & $24.88^{b, a}$ & $25.48^{\mathrm{ab}, \mathrm{a}}$ \\
\hline & 7 & $25.60^{\mathrm{a}, \mathrm{a}}$ & $25.08^{\mathrm{b}, \mathrm{a}}$ & $25.09^{\mathrm{b}, \mathrm{a}}$ & $24.86^{b, a}$ & $25.49^{a b, a}$ \\
\hline & 14 & $25.62^{\mathrm{a}, \mathrm{a}}$ & $25.09^{b, a}$ & $25.09^{\mathrm{b}, \mathrm{a}}$ & $24.87^{\mathrm{b}, \mathrm{a}}$ & $25.48^{\mathrm{ab}, \mathrm{a}}$ \\
\hline \multirow{3}{*}{$\begin{array}{c}\text { Protein/DM } \\
\%\end{array}$} & Fresh & $70.27^{\mathrm{d}, \mathrm{a}}$ & $63.92^{\mathrm{c}, \mathrm{a}}$ & $65.24^{\mathrm{c}, \mathrm{a}}$ & $67.88^{\mathrm{b}, \mathrm{a}}$ & $68.45^{\mathrm{a}, \mathrm{a}}$ \\
\hline & 7 & $70.24^{\mathrm{d}, \mathrm{a}}$ & $64.09^{\mathrm{c}, \mathrm{a}}$ & $65.25^{\mathrm{c}, \mathrm{a}}$ & $67.01^{\mathrm{b}, \mathrm{a}}$ & $69.38^{\mathrm{a}, \mathrm{a}}$ \\
\hline & 14 & $70.94^{\mathrm{d}, \mathrm{a}}$ & $64.20^{\mathrm{c}, \mathrm{a}}$ & $67.44^{\mathrm{c}, \mathrm{a}}$ & $66.14^{\mathrm{b}, \mathrm{a}}$ & $68.96^{\mathrm{a}, \mathrm{a}}$ \\
\hline \multirow[t]{3}{*}{ Fat \% } & Fresh & $0.8^{\mathrm{b}, \mathrm{b}}$ & $0.8^{\mathrm{b}, \mathrm{b}}$ & $0.9^{\mathrm{a}, \mathrm{b}}$ & $0.6^{b, b}$ & $1.0^{\mathrm{a}, \mathrm{b}}$ \\
\hline & 7 & $0.7^{\mathrm{b}, \mathrm{ab}}$ & $0.7^{\mathrm{b}, \mathrm{ab}}$ & $1.0^{\mathrm{a}, \mathrm{ab}}$ & $0.7^{\mathrm{b}, \mathrm{ab}}$ & $0.8^{\mathrm{a}, \mathrm{ab}}$ \\
\hline & 14 & $0.7^{\mathrm{b}, \mathrm{a}}$ & $0.8^{\mathrm{b}, \mathrm{a}}$ & $0.8^{\mathrm{a}, \mathrm{a}}$ & $0.8^{\mathrm{b}, \mathrm{a}}$ & $0.9^{\mathrm{a}, \mathrm{a}}$ \\
\hline \multirow[t]{3}{*}{ Ash\% } & Fresh & $1.877^{\mathrm{a}, \mathrm{a}}$ & $1.877^{\mathrm{ab}, \mathrm{a}}$ & $1.866^{\mathrm{bc}, \mathrm{a}}$ & $1.875^{\mathrm{bc}, \mathrm{a}}$ & $1.886^{\mathrm{c}, \mathrm{a}}$ \\
\hline & 7 & $1.876^{\mathrm{a}, \mathrm{a}}$ & $1.867^{\mathrm{ab}, \mathrm{a}}$ & $1.865^{\mathrm{bc}, \mathrm{a}}$ & $1.867^{\mathrm{bc}, \mathrm{a}}$ & $1.866^{\mathrm{c}, \mathrm{a}}$ \\
\hline & 14 & $1.887^{\mathrm{a}, \mathrm{a}}$ & $1.877^{\mathrm{ab}, \mathrm{a}}$ & $1.880^{\mathrm{bc}, \mathrm{a}}$ & $1.874^{\mathrm{bc}, \mathrm{a}}$ & $1.872^{\mathrm{c}, \mathrm{a}}$ \\
\hline \multirow[t]{3}{*}{ Salt \% } & Fresh & $1.357^{\mathrm{a}, \mathrm{a}}$ & $1.367^{b, a}$ & $1.159^{\mathrm{c}, \mathrm{a}}$ & $1.340^{\mathrm{a}, \mathrm{a}}$ & $1.330^{\mathrm{a}, \mathrm{a}}$ \\
\hline & 7 & $1.324^{\mathrm{a}, \mathrm{a}}$ & $1.324^{b, a}$ & $1.148^{\mathrm{c}, \mathrm{a}}$ & $1.368^{\mathrm{a}, \mathrm{a}}$ & $1.387^{\mathrm{a}, \mathrm{a}}$ \\
\hline & 14 & $1.346^{\mathrm{a}, \mathrm{a}}$ & $1.135^{\mathrm{b}, \mathrm{a}}$ & $1.135^{\mathrm{c}, \mathrm{a}}$ & $1.327^{\mathrm{a}, \mathrm{a}}$ & $1.264^{\mathrm{a}, \mathrm{a}}$ \\
\hline \multirow[t]{3}{*}{ Acidity \% } & Fresh & $0.54^{\mathrm{a}, \mathrm{a}}$ & $0.46^{\mathrm{a}, \mathrm{a}}$ & $0.43^{\mathrm{ab}, \mathrm{a}}$ & $0.36^{\mathrm{b}, \mathrm{a}}$ & $0.40^{\mathrm{ab}, \mathrm{a}}$ \\
\hline & 7 & $0.63^{\mathrm{a}, \mathrm{a}}$ & $0.52^{\mathrm{a}, \mathrm{a}}$ & $0.50^{\mathrm{ab}, \mathrm{a}}$ & $0.47^{\mathrm{b}, \mathrm{a}}$ & $0.54^{\mathrm{ab}, \mathrm{a}}$ \\
\hline & 14 & $0.70^{\mathrm{a}, \mathrm{a}}$ & $0.56^{\mathrm{a}, \mathrm{a}}$ & $0.72^{\mathrm{ab}, \mathrm{a}}$ & $0.60^{b, a}$ & $0.66^{\mathrm{ab}, \mathrm{a}}$ \\
\hline \multirow[t]{3}{*}{$\mathrm{pH}$ value } & Fresh & $5.00^{\mathrm{a}, \mathrm{a}}$ & $5.11^{\mathrm{a}, \mathrm{a}}$ & $5.25^{\mathrm{a}, \mathrm{a}}$ & $5.13^{\mathrm{a}, \mathrm{a}}$ & $4.98^{\mathrm{a}, \mathrm{a}}$ \\
\hline & 7 & $4.40^{\mathrm{a}, \mathrm{a}}$ & $4.60^{\mathrm{a}, \mathrm{a}}$ & $4.50^{\mathrm{a}, \mathrm{a}}$ & $4.60^{\mathrm{a}, \mathrm{a}}$ & $4.70^{\mathrm{a}, \mathrm{a}}$ \\
\hline & 14 & $4.20^{\mathrm{a}, \mathrm{a}}$ & $4.30^{\mathrm{a}, \mathrm{a}}$ & $4.20^{\mathrm{a}, \mathrm{a}}$ & $4.30^{\mathrm{a}, \mathrm{a}}$ & $4.40^{\mathrm{a}, \mathrm{a}}$ \\
\hline
\end{tabular}

CFU: colony forming unit.

PFU: plaque forming unit.

The letters before comma possess the factor of contamination with $1 \%$ Salmonella suspension. While those after comma possess the factor of spiking level with Salmonella typhimurium phage suspension. The means with the same letter at any position did not significantly differ $(P>0.05)$.

Regarding the fat content, due to the Kariesh cheese made from skimmed milk, the low fat content was slightly significant affected either by the level phage suspension added or the CSP of resultant product and did not exhibited any obvious trends.

With regard to the ash content of Kariesh cheese as a function of the spiking level with phage suspension data revealed that, similar to that occurred in the DM\%, the ash content gradually declined as the phage level raised, nevertheless, the prolonging of CSP did not lead to any significant changes in the ash level of cheese.
While, The salt content in Kariesh cheese appeared different responses towards the spiking level with phage suspension, while the CSP caused nonsignificant differences in the criterion .

Moreover, the statistical analysis declared that the acid development was significantly slowed due to the presence of phage suspension at any level. Nevertheless the differences in the TA\% of cheese along the CSP were not significant.

Furthermore, the $\mathrm{pH}$ value of cheese did not exhibit any significant changes whether among the spiking level of the phage suspension or along the CSP for 14 days. 
As a conclusion, the spiking of Kariesh cheese milk with $1 \%$ Salmonella typhimurium phage suspension $\left(10^{8} \mathrm{PFU} / \mathrm{mL}\right)$ is quite enough to eliminate this microorganism when it present at a count as that gained when contaminated with $1 \%$ suspension containing $10^{5}$ CFU S. typhimurium $/ \mathrm{mL}$. was added.

\section{REFERANCES}

Abd El-Salam, M.H., El-Shibiny, S. and Fahmi, A.H. 1976. Domiati cheese. A review. NZ. J. Dairy Sci. and Technol., 11, 57- 61.

Abd-El Salam, M. and Benkerroum, N. 2006. North African Brined Cheeses. In: Brined Cheeses. pp. 139-187. (A. Tamime, Ed.), Blackwell Pub. Ltd, UK.

Abou-Donia, S.A. 1984. Egyptian fresh fermented milk products. NZ, J. Dairy Sci. Technol., 19, 7-18.

Abou Donia, S.A. 1991. Manufacture of Egyptian, soft, pickled cheeses. In: Feta and Related Cheeses (R.K. Robinson and A.Y. Tamime, Eds), pp. 160-208. Ellis Horwood, London, UK.

Abou-Donia, S.A. 1999a. Geographical distribution and historical development of Ancient Egyptian dairy products. Egypt. J. Dairy Sci., 27, 359-368.

Abou-Donia, S.A. 1999b. Importance of Fermented Milks and Related Cheese in the Egyptian Diet. Proc. the Alexandria Symp. on Starter Cultures and their Use in Dairy Industry. Alexandria Egypt, Nov.12-13, pp. 108-114.

Abou-Donia, S.A. 2008. Origin, History and Manufacturing Process of Egyptian Dairy Products: An Overview Alex. J. Food Sci. Technol., 5, 51-62.

AOAC 2007. Association of Official Analytical Chemists. Official Method of Analysis. $\left(18^{\text {th }}\right.$ Ed.), pp. 302-850. Benjamin Franklin Station Washington, D.C., USA.

Bakry, S.S., Mohran, M.A., Gomah, N.H. and Essawy, E.A. 2011. Gross composition of milk and dairy products in Assiut villages. Assiut $\mathbf{J}$. Agric Sci., 42, 34-46.

Borrego, J.J., Morifiigo, M.A., de Vicente, A., Cornax, R. and Romero, P. 1987. Coliphages as an indicator of faecal pollution in water. Its relationship with indicator and pathogenic microorganisms. War. Res., 21, 1473-1480.

D'Herelle, F. 1917. Sur un microbe invisible antagoniste bacilles des dysentériques. C.R. Hebd. Seances Acad. Sci. D. 165, 373-375.
De Man, J.C., Rogosa, M. and Sharp, M.E. 1960. A medium for the cultivation of Lactobacilli. $\mathbf{J}$. Appl. Baeteriol., 23, 130-136.

El-Gendy, S. 1983. Fermented foods of Egypt and the Middle East. J. Food Prot., 46, 358 - 367.

El-Sayed, M.A., Hosny, I.M., El-Kholy, W.I., El-Dairouty, R.K. and Mohamed, S.H.S. 2011. Microbiological evaluation of Egyptian white soft cheeses style. J. Amer. Sci., 7, 517526.

EOSQ 2005. Egyptian Organization for Standardization and Quality. Soft cheese Part 5: Kariesh cheese, Egyptian Standard (ES) 1007 / 2005.

Fahmi, A.H. 1950. Studies On Kareish Cheese. Ph.D. Thesis, Univ. of Reading, England. pp. 1-50.

Fayed, A.E. 1986. Protein fortification of some dairy products. Ph.D. Thesis, Fac. of Agric. Ain Shams Univ., Egypt. pp.1-14.

Fayed, A.E.' Farahat, A.M., Metwally, A.E., Massoud' M.S. and Emam, A.O. 2013. Rheological, microstructural and biological characteristics of probiotic ultrafiltrated skimmed milk cheese in comparison with the conventional Kariesh cheese. Proc. $6^{\text {th }}$ Ann. Appl. Res. Environ. Prot. \& Agric. Dev., Feb. 27-28. And J. Biol. Chem. Environ. Sci., 8, 163-198.

Fayed, A.E., Farahat, A.M., Metwally, A.E., Massoud, M.S. and Emam, A.O. 2014. Health stimulating properties of the most popular soft cheese in Egypt "Kariesh" made using skimmed milk UF-retentate and probiotics. Acta Sci. Pol., Technol. Aliment., 13, 359-373.

Goodridge, L., Gallaccio, A. and Griffiths, W.M. 2001. Morphological,host range, and genetic characterization of two coliphages. Appl. Environ. Microbial., 69, 5364-5371.

Guttman, B., Raya, R. and Kutter, E. 2005. Basic phage biology,. In: E. Kutter and A. Sulakvelidze (eds.), Bacteriophages: Biology and Application. CRC Press, Boca Raton, Florida, USA. pp. 29-66.

Hagens, S. and Loessner, M.J. 2007. Application of bacteriophages for detection and control of foodborne pathogens, Apple. Microbiol Biotechnol., 76, 513-519.

Hassan, G.M. and Gomaa, S.M. 2016. Microbiological quality of soft cheese marketed in Cairo and Giza governorates. Alex. J. Vet. Sci., 50, 18-23. 
Hegazy, M.I. and Mahgoub, S.A. 2013. Microbiological characterization of the Egyptian soft white cheese and identification of its dominant yeasts. Afr. J. Microbiol. Res., 7, 2205-2212.

Holt, J.G., Krieg, N.R., Sneath, P.H.A., Stanley, J.T. and William, S.T. 1994. Bergey's Manual of Determinative Bacteriology. $9^{\text {th }} \mathrm{Ed}$., pp. 786788. Williams and Wilikins Publ., Baltimore, Maryland, USA.

Ibrahim, E.M.A. and Sobeih, A.M.K. 2010. Effect of packaging containers on the bacteriological profile of soft cheese. Global Veterinaria, 4, 349-356.

Ibrahim, J.I., Salama, E., Saad, A. and Helmy, A.A. 2015. Microbial quality of some dairy products in Ismailia City. $2^{\text {nd }}$ Conf. Food Safety, Aug., Fac. Vet. Medicine, Suez Canal Univ., I, 14-21.

Kalkan, S., Unal, E. and Erginkaya, Z. 2011. BioControl of some Food-Born Pathogenic Baacteria by Bacteriophage. J. Food Sci. and Engineering 1, 237-244

Kotterer, R. and Munch, S. 1978. Untersuchungs verfahren fur das Milcwirtschaftliche Laboratorium. Munchen: Volkswirtschaftliche Verlag $\mathrm{GmbH}, 201$ p.

Lim, Y.H., Hirose, K., Izumiya, H., Arakawa, E., Takahashi, H., Terajima, J., Itoh, K., Tamura,
K., Kim, S.I. and Watanabe, H. 2003. Multiplex polymerase chain reaction assay for selective detection of Salmonella enterica serovar typhimurium. Jpn. J. Infect. Dis., 56, 151-155.

Lindqvist, R., Sylven, S. and Vagsholm, I. 2002. Quantitative microbial risk assessment exemplified by Staphylococcus aureus in unripened cheese made from raw milk. Int. J. Food Microbiol., 78, 155-170.

Luftig, R.B. 1967. Studies on cyanophage LPP-1. Ph.D. Thesis. Univ. of Chicago, USA.pp. 1-40.

McLntryre, L., Hudson, J.A., Billington, C. and Withers, H. 2007. Biocontrol of Foodborne Bacteria: Past, Present and Future Strategies, Scientific Supplement August/September, New Zealand, pp. 25-32.

Othman, B.A. 1997. Isolation of lambida bacteriophage $\beta 4 E C$ from sewage polluted drinking water. Proc. of the $10^{\text {th }}$ Conf. of Microbiol., pp. 7888, March 25-27, Cairo, Egypt

Othman, B.A., Askora, A.A., Nadia, M.A. and Amel, S.A. 2008. Characterization of virulent bacteriophages for Strptomyces Griseoflavus isolated from SOI. Pak. J. Biotechnol., 5, 109119.

SPSS 1998. Statistical Package for Social Sci., SPSS Inc., 444, North Michingan Avenue, Chicago, Illinois, USA. 


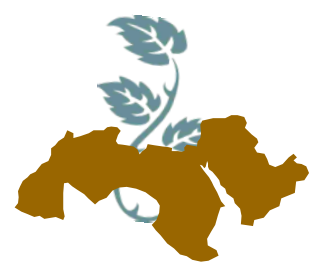

1893

مجلة اتحاد الجامعات العربية

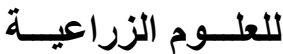

جامعة عين شمس ، الترد ، القاهرة

مجلد(26)، عدد (2C)، شدل ، عدد خاص ، 1881 - 1894، 2018

\title{
عزل و تعريف والتحكم الحيوي لميكروب Salmonella typhimurium فى الجبن
}

القريش بإستخدام البكتيروفاج

[138]

\author{
منى صبرى على 1 - راجيه عمر محمد 1 - مصطفى عبد الله حسن2 - عاطف السيد فايد2 \\ 1- معهذ بحوث تكنوولجيا الأغذية - مركز البحوث الزراعية - جيزة - مصر \\ 2- قسم علوم الأغذية - كلية الزراعة - جامعة عين شمس - صدية البع. 68 حدائق شبرا 11241 - القاهرة - مصر
}

بمقدار 2\% من بادئ اليوجهورت الطازج النشط ثم قسم

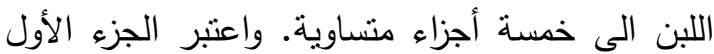
كعينه مقارنه بينما نم تلويث كل من الأجزاء من الثانى الأن

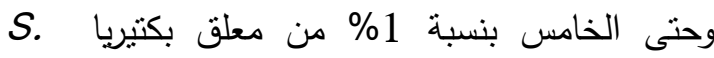
typhimurium

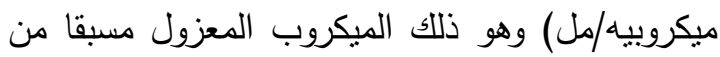

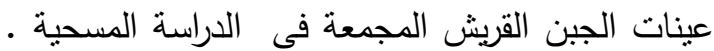

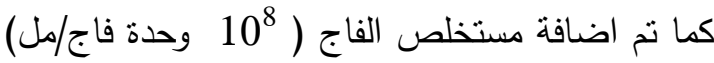
المعزول من عينات مياه الصرف الصدي الصاج الصى أقتسام

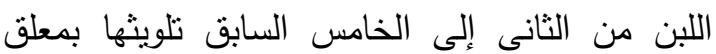

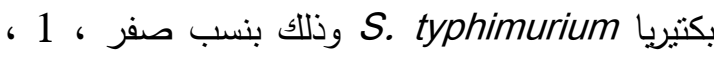
2 و 3\% من معلق الفاج على التوالي. ثم تحضين

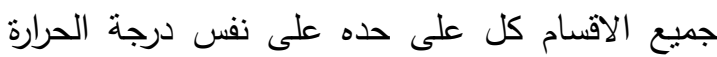
حتى تمام التجبن. نم تقطيع الخثرة ونقلها كل على التى حده

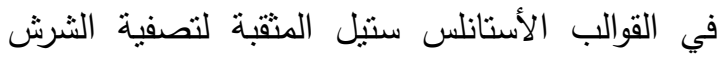

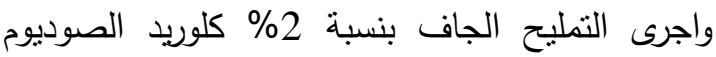
ونقلت كل على حده ووضعت في عبوات بلات بلاستيك

لحفظها.

ولقد أوضحت النتائج فى العينات التجريبية المصنعة

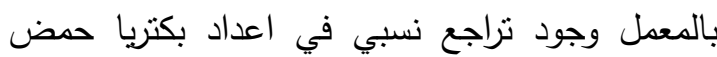

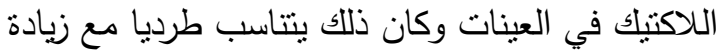
نسبة الفاج المضافة ، كما الخفضات وكان ذلبكأ أعداد بكتريا حمض اللاكتيك على مدار فترة التخزين. ومن ناحية السلامة الغذائية فقد حدث انخفاض تدريجي في غياب
الكلمات الدالة: التعريف بواسطة سلسلة تفاعل البوليميريز - الفحص بالميكروسكوب الالكترونى للفاج

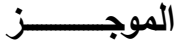

تهدف هذه الدراسة الى إمكانية التحكم الحيوي

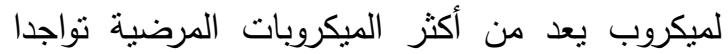

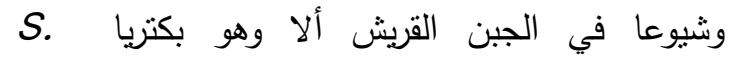
.typhimurium ولتحقيق هذا الهدف نم أولا تجميع 20 عينة من الجبن القريش عشوائيا من مختلف الأسواق المحلية

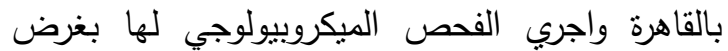
عزل وتعريف بكتريا S. typhimurium S. تواجدها بها. اوضحت النتائج المتحصل عليها typhimurium نواجدت فى 30\% من العينات المجمعة من الأسواق وتم إجراء تعريف لها بإستخدام

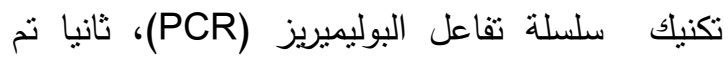
تجميع 5 عينات من مياه الصرف من محطة مياه الثرب والصرف الصحي بكلية الزراعه جامعة عين

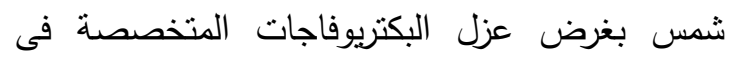

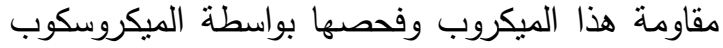

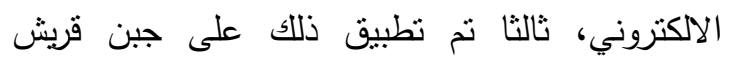
تجريبي مصنع بالمعمل من لبن فرز جاموسي مبستر حيث لقح اللبن عند درجة حرارة 40 درجة مئوية 
S. typhimurium السابقين وهما التلويث ببكتيريا

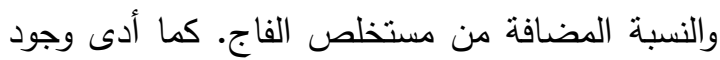

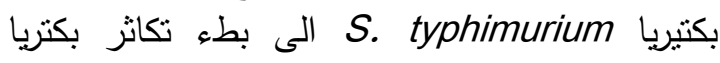

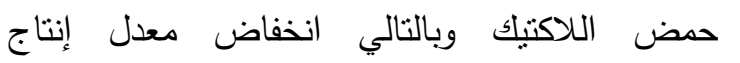

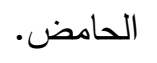

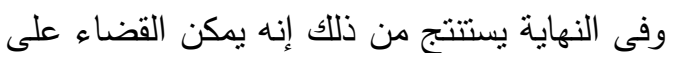

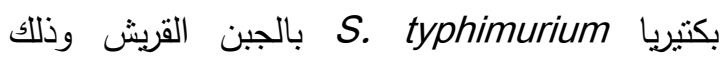

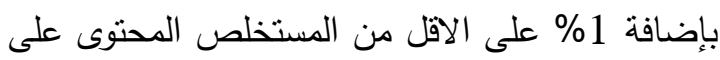

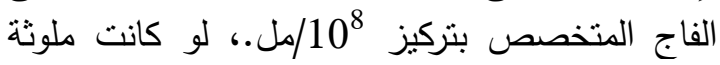

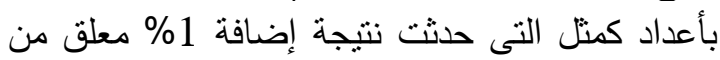
بكتيريا S. typhimurium المحتوى على $10^{5}$ خليه

$$
\text { ميكروبيه/مل. }
$$

الفاج لأعداد S. typhimurium المضافة كنتيجة

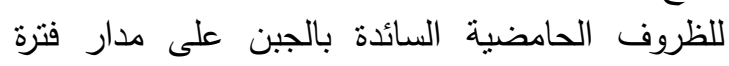
التخزين المبرد ولكنها ظلت موجودة حتى نهاية الفترة

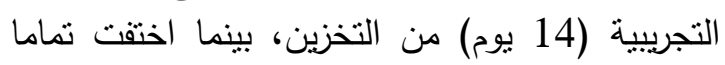

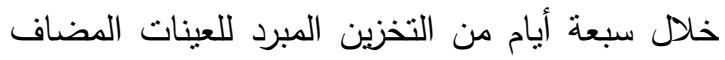

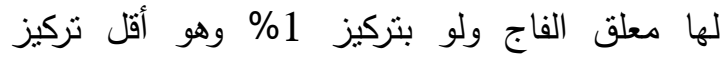

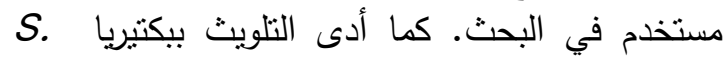
typhimurium الى تقليل قابلية الجبن القريش لتصفية التصنية

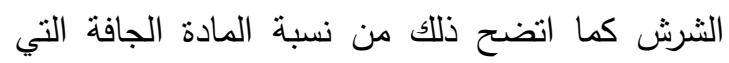

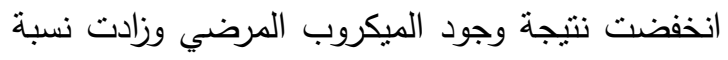

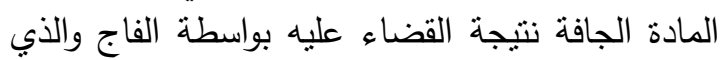
أدى ايضا الى زيادة المحتوى البروتيني للمادة الجافة الجية

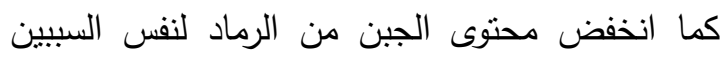


1893

مجلة اتحاد الجامعات العربية

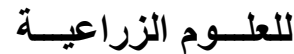

جامعة عين شمس ، القراهرة

مجلا(26)، عدد (2C)، عدد خاص ، 1881 - 1894، 2018

تحكيم: ا.د منيـر محمود العبـــ

ا.د يوسف مرسى الكنانى 